\title{
Serum Soluble CD163 as a Predictor of Esophageal Varices and Variceal Bleeding in Cirrhotic Patients
}

Mahmoud Rizk*1, Ahmed Mohamed Hussein ${ }^{1}$, Amany A. Amer ${ }^{2}$, Mohamed Abd Ellatif Afifi ${ }^{1}$

${ }^{1}$ Department of Internal Medicine, Hepatology and Gastroenterology Unit, Benha University, Egypt

${ }^{2}$ Department of Tropical Medicines, Faculty of Medicine, Menoufia University, Egypt

*Corresponding Author: Mahmoud Rizk, Mobile: (+20)1117454801, Email: Mahmoudrizk70@yahoo.com

\begin{abstract}
Background: Bleeding of esophageal varices (OV) is also bearing elevated mortality in patients with liver cirrhosis (LC). The best standard diagnostic investigation for OV is upper gastrointestinal (GI) endoscopy. Patients and endoscopic units alike are burdened by the endoscopic screening of all patients with liver cirrhosis. The use of non-invasive OV detection reduces the need for endoscopic screening.

Objective: The aim of the current work was to test serum soluble CD 163(sCD163) as a predictor of the presence, and grade of $\mathrm{OV}$ and as non-invasive indicator of having severe variceal bleeding.

Patients and Methods: This cross-sectional study included a total of 70 cirrhotic patients, attending at the Hepatology and Gastroenterology Unit, Department of Internal Medicine, Benha University Hospital, Egypt. To detect OV, all patients underwent upper GI endoscopy, and serum sCD163 levels were assessed using an ELISA technique.

Results: Patients with OV had a higher mean value of sCD163 levels $(8.71 \pm 8.42 \mathrm{ng} / \mathrm{ml})$ than patients without OV $(2.89 \pm 1.02 \mathrm{ng} / \mathrm{ml})$, however this was not statistically significant $(\mathrm{P}=0.13)$. sCD163 level was significantly higher in large OV group $(10.75 \pm 9.26 \mathrm{ng} / \mathrm{ml})$ than small OV group $(3.75 \pm 0.92 \mathrm{ng} / \mathrm{ml}),(\mathrm{P}=0.001)$. The rate of significant variceal bleeding is closely linked to serum higher sCD163 levels more than $(4.63 \mathrm{ng} / \mathrm{ml})$.

Conclusion: It could be concluded that serum SCD163 could be a non-invasive indicator of the presence of OV in cirrhotic patients. It may also be used for the prediction of the size of OV and the probability of severe variceal bleeding.
\end{abstract}

Keywords: Serum soluble CD163, Esophageal varices, Variceal bleeding, Cirrhotic patients

\section{INTRODUCTION}

Cirrhosis of the liver develops as a consequence of systemic fibrosis which is the end result of all chronic hepatic diseases. High portal pressure and hepatic dysfunction may occur as a consequence of LC. Both of these may cause a variety of problems, including ascites, OV, hepatic encephalopathy (HE), hepatocellular carcinoma (HCC), hepatopulmonary syndrome, and coagulation disturbances, either alone or in combination ${ }^{(\mathbf{1})}$.

Portal hypertension is a gradual, unavoidable consequence of LC that contributes to the development of porto-systemic shunts, of which the OV has the greater clinical impact due to the risk of fatal bleeding if it ruptures. The gold standard for diagnosing $\mathrm{OV}$ is upper GI endoscopy, which is advised by all guidelines to scan all cirrhotic patients for $\mathrm{OV}$ at the time of diagnosis. Repeat endoscopy is recommended for nonvariceal decompensated cirrhotic patients per year, and every two or three years for paid patients ${ }^{(2)}$.

The vast majorities of cases undergoing screening endoscopy either may not have varices or do have varices but do not need prophylactic treatment.

As a result, the development of non-endoscopic, non-invasive diagnostic methods that can reliably predict the existence of $\mathrm{OV}$ in cirrhotic patients, especially those with large OV, can aid in the early detection of patients that are most at risk and therefore reduce the need for endoscopic screening ${ }^{(3)}$.

Kupffer cells, which make up more than $80 \%$ of all macrophages in the body, have been shown to play a key role in liver inflammation and fibrosis as well as the pathogenesis of portal hypertension ${ }^{(4)}$. SCD163 is a haemoglobin haptoglobin scavenger receptor unique to macrophages and a specific marker for macrophage activation (5). After Toll-like receptor activation, sCD163 is shed into the bloodstream in a soluble shape known as SCD $163^{\left({ }^{(}\right)}$.

sCD163 levels in the blood are accordingly elevated during macrophage activation and proliferation ${ }^{(7)}$.

sCD163 is a responsive marker of macrophage activation that has been linked to the severity of portal hypertension in patients with cirrhosis ${ }^{(8)}$.

The aim of this research was to see whether serum SCD 163 could be used as a non-invasive indicator of the existence and size of $\mathrm{OV}$ and if it could predict variceal bleeding in cirrhotic patients.

\section{PATIENTS AND METHODS}

This cross-sectional study included a total of 70 cirrhotic patients, attending at the Hepatology and Gastroenterology Unit, Department of Internal Medicine, Benha University Hospital, Egypt. 


\section{Ethical Consideration:}

This study was ethically approved by the Ethical Committee of Benha Faculty of Medicine and its university hospitals. Before enrolling in the study, informed consent was obtained from each participant.

All patients met the diagnostic criteria of LC by clinical, biochemical, and ultrasonographic findings. Patients were divided according to the results of the upper GI endoscopy into the following groups (Figure 1):

Group I: Included 5 patients with LC with no endoscopic evidence of OV (Non-OV)

Group II: Included 65 patients with LC with OV, which was subdivided according to the size of OV into 2 subgroups as per the American Association for the Study of Liver Diseases (AASLD):

- Group IIa: Included 19 patients with small OV

- Group IIb: Included 46 patients with large OV

\section{Exclusion criteria:}

- Patients under the age of eighteen.

- Patients who had a history of OV treatment, sclerotherapy, or endoscopic variceal ligation.

- Patients taking beta-blockers, nitrates, or other pharmacological agents that lower portal hypertension.

- Patients with HCC and patients for whom endoscopy was not recommended.

\section{All patients were subjected to:}

(i) Take a thorough biography and history

(ii) Clinical examination for LC and portal

\section{Cirrhotic patients}

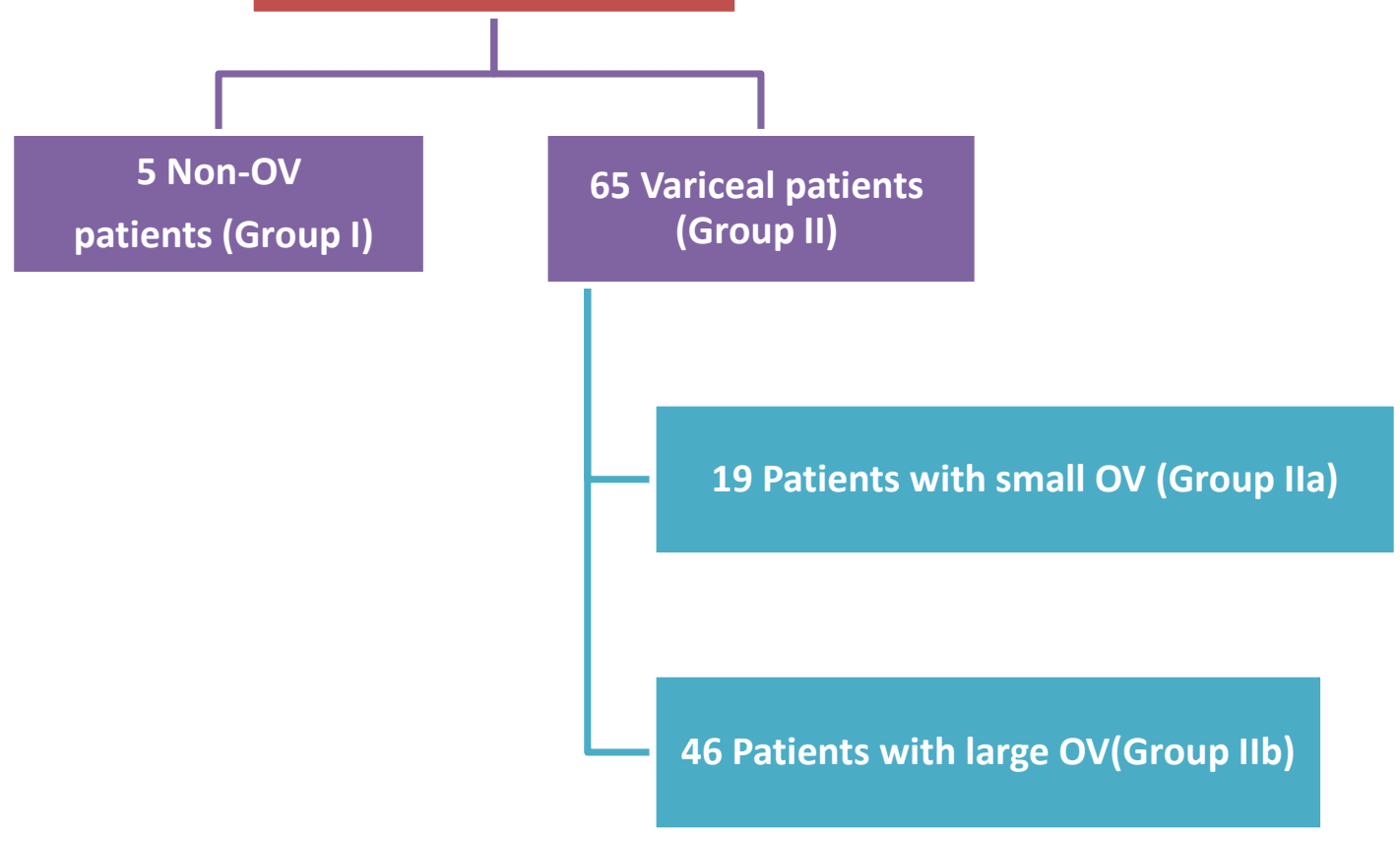

Figure (1): Patients were divided according to the results of the upper GI endoscopy into the shown groups.

For categorical variables, descriptive statistics hypertension symptoms such as ascites and splenomegaly

(iii) Determination of biochemical criteria, including complete blood count (CBC), serum albumin $(\mathrm{g} / \mathrm{dl})$, serum bilirubin $(\mathrm{mg} / \mathrm{dl})$, international normalized ratio (INR), and Child-Pugh classification.

(iv) ELISA technique was used for determination of the research marker "sCD 163". According to the manufacturer's recommendations, the research was performed using a Human sCD163 ELISA Kit supplied by SunRed biotechnology company in Shanghai, China. The kit uses a doubleantibody sandwich ELISA technique.

(v) An abdominal ultrasonographic test was performed in order to assess the following:

a. Characteristic Features of liver cirrhosis (coarse echopattern, wavy irregular outline, attenuated hepatic veins, prominent caudate lobe, shrunken liver).

b. Spleen length (measured from a left lateral cross-section).

c. The diameter of the portal vein (PV).

d. The presence or absence of ascites and exclusion of HCC.

(vi) Upper GI endoscopy was done by Olympus video endoscopy, presence of $\mathrm{OV}$ and grading of its size were done

Ultrasound and endoscopy examinations were performed by experienced Gastroenterology trainees (> 3 years' experience) and senior consultants.

\section{Patients with small OV (Group Ila)}

\section{Patients with large OV(Group IIb)}


were provided in the form of frequencies and percentages; for numerical variables, descriptive statistics were presented in the form of mean, standard deviation, minimum, and limit. The features of patients with OV and those who were not were compared using (Chi-square test or Fisher exact test) for categorical variables, and the separate t-test for numerical variables. When testing for the other variables, a multiple logistic regression analysis test was used to investigate the relationship between the various variables and the existence of OV. The sensitivity, specificity, positive predictive value (PPV), and negative predictive value (NPV) were measured for the cut-off points selected based on the receiver operating characteristic (ROC). The research was performed using IBM SPSS version 26 for Windows applications. A (p-value) of less than 0.05 is regarded as statistically significant.

\section{RESULTS}

The 70 cirrhotic patients in this sample were divided into two groups: group I consisted of 5 cirrhotic patients without OV and group II consisted of 65 cirrhotic patients with OV, 48 of whom were males and 22 of whom were females with a mean age of $53.6 \pm 6.19$ years for group I and 57.12 \pm 8.8 years for group II. Child A was assigned to 21 patients, the same like Child B which was assigned to the same number (21 patients), while Child $\mathrm{C}$ was assigned to 28 patients. Ascites and splenomegaly affect about 67 percent and 80 percent of our patients, respectively (Tables $1 \&$ 2).

Comparison of the characteristics of the categorical variables between group I and group II was done using Chi squares test. There were statistically significant differences between them regarding ChildPugh score, ascites, and splenomegaly. Most of patients in group I were Child A (80\%), while most patients in group II were Child B and C (73.8\%). The percentage of ascites in the Non-OV group was $20 \%$, which is much lower than that of the OV group $(70.8 \%)$, and the percentage of splenomegaly in the Non-OV group was $20 \%$, which is much lower than that of the OV group (84.6\%) (Table 1).

When the characteristics of categorical variables were compared between groups IIa and IIb, there was a statistically high significant difference
Pugh score, splenomegaly, and ascites 3).

(Table

The independent t-test was used to compare the characteristics of the studied groups in terms of numerical variables. Platelet count, serum bilirubin, and serum albumin levels all showed statistically significant differences. Platelet count was lower in the OV group $(102.58 \pm 59.55)$ compared to the Non-OV group $(164.6 \pm 79.63)$ and in patients with large OV (95.04 \pm 60.71$)$ compared to those with small varices (130.26 \pm 47.59$)$. Serum albumin was lower in the OV group $(2.62 \pm 0.42)$ compared to the Non-OV group $(3.38 \pm 0.13)$ and in patients with large OV $(2.51 \pm 0.40)$ compared to those with small OV $(2.89 \pm 0.35)$. Serum bilirubin was higher in the OV group $(1.83 \pm 1.18)$ compared to the Non-OV group $(0.76 \pm 0.05)$. There was no significant difference as regards values of the other laboratory parameters included in the study.

The mean value of sCD163 levels in patients with OV was higher $(8.71 \pm 8.42 \mathrm{ng} / \mathrm{ml})$ in comparison to patients without $\mathrm{OV}(2.89 \pm 1.02 \mathrm{ng} / \mathrm{ml})$ but this was not statistically significant $(\mathrm{P}=0.13)$ (Table 2), however, it was statistically significant higher in patients having large OV (Group IIb) $(10.75 \pm 9.26)$ than those with small ones OV (Group IIa) (3.75 \pm 0.92 (Table 4).

There was a statistically significant difference between patients with small OV and those with large $\mathrm{OV}$ as regards major variceal bleeding $(\mathrm{P}<0.05)$ (Table 5).

sCD163 at a cut-off value $\geq 3.58$ had $90.8 \%$ sensitivity, $80 \%$ specificity, $98.3 \%$ PPV, and $40 \%$ NPV for detection of OV (Table 6), with AUC $=0.93$ (Figure 2) and at cut-off value $\geq 4.45$, it had $89.1 \%$ sensitivity, $84.2 \%$ specificity, $93.2 \%$ PPV, and $76.2 \%$ NPV for diagnosis of large OV (Table 6) with AUC = 0.95 (Figure 3), and at cut-off value $\geq 4.63$, it had a sensitivity of $70.7 \%$, specificity of $54.2 \%$, PPV of $72.5 \%$ and NPV of $52 \%$ for prediction of major variceal bleeding in cirrhotic patients with OV (Table 7) with $\mathrm{AUC}=0.62$ (Figure 4).

On analyzing the association between the different patients' parameters and the incidence of major variceal bleeding, only large $\mathrm{OV}$ and serum sCD163 level $\geq 4.63(\mathrm{ng} / \mathrm{ml})$ are strongly associated with the incidence of major variceal bleeding (Table 8). 
Table (1): Comparison of the characteristics (categorical variables).

\begin{tabular}{|c|c|c|c|c|}
\hline 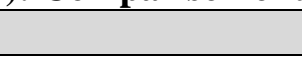 & & Group I (Non- OV) & Group II (OV) & $P$ value \\
\hline \multirow[t]{2}{*}{ Sex } & Male & $\begin{array}{c}3 \\
60 \%\end{array}$ & $\begin{array}{c}45 \\
69.2 \%\end{array}$ & \multirow[b]{2}{*}{0.65} \\
\hline & Female & $\begin{array}{c}2 \\
40 \%\end{array}$ & $\begin{array}{c}20 \\
30.8 \%\end{array}$ & \\
\hline \multirow[t]{3}{*}{ Child-Pugh score } & A & $\begin{array}{c}4 \\
80 \%\end{array}$ & $\begin{array}{c}17 \\
26.2 \%\end{array}$ & \multirow{3}{*}{0.032} \\
\hline & B & $\begin{array}{c}1 \\
20 \%\end{array}$ & $\begin{array}{c}20 \\
30.8 \%\end{array}$ & \\
\hline & $\mathrm{C}$ & $\begin{array}{c}0 \\
0 \%\end{array}$ & $\begin{array}{c}28 \\
43 \%\end{array}$ & \\
\hline \multirow[t]{2}{*}{ Ascites } & No & $\begin{array}{c}4 \\
80 \%\end{array}$ & $\begin{array}{c}19 \\
29.2 \%\end{array}$ & \multirow{2}{*}{0.037} \\
\hline & Yes & $\begin{array}{c}1 \\
20 \%\end{array}$ & $\begin{array}{c}46 \\
70.8 \%\end{array}$ & \\
\hline \multirow[t]{2}{*}{ Splenomegaly } & No & $\begin{array}{c}4 \\
80 \%\end{array}$ & $\begin{array}{c}10 \\
15.4 \%\end{array}$ & \multirow{2}{*}{0.005} \\
\hline & Yes & $\begin{array}{c}1 \\
20 \%\end{array}$ & $\begin{array}{c}55 \\
84.6 \%\end{array}$ & \\
\hline
\end{tabular}

Table (2): Comparison of the characteristics (numerical variables)

\begin{tabular}{|c|c|c|c|c|c|}
\hline & \multicolumn{2}{|c|}{$\begin{array}{c}\text { Group I } \\
(\text { Non-OV) }\end{array}$} & \multicolumn{2}{|c|}{$\begin{array}{c}\text { Group II } \\
(\mathbf{O V})\end{array}$} & \multirow[t]{2}{*}{ P value } \\
\hline & Mean & SD & Mean & SD & \\
\hline Age (years) & 53.6 & 6.19 & 57.12 & 8.8 & 0.38 \\
\hline Hemoglobin $(\mathrm{g} / \mathrm{dl})$ & 9.26 & 2.11 & 8.84 & 2.15 & 0.68 \\
\hline Total leucocytic count $\left(\times 10^{3} / \mathrm{ul}^{\prime}\right)$ & 7.88 & 1.93 & 6.16 & 1.29 & 0.26 \\
\hline Platelet count $\left(\mathrm{x10}^{3} / \mathrm{ul}\right)$ & 164.6 & 9.63 & 102.58 & 9.55 & 0.032 \\
\hline AST (U/L) & 59.4 & 11.13 & 55.86 & 2.89 & 0.71 \\
\hline $\operatorname{ALT}(\mathbf{U} / \mathbf{L})$ & 53.0 & 7.54 & 54.72 & 4.03 & 0.88 \\
\hline INR & 1.35 & 0.37 & 1.48 & 0.35 & 0.43 \\
\hline Serum creatinine (mg/dl) & 1.22 & 0.2 & 1.38 & 0.08 & 0.10 \\
\hline Serum Na $(\mathrm{mEq} / \mathrm{L})$ & 137.8 & 5.26 & 133.8 & 6.5 & 0.19 \\
\hline Total Bilirubin (mg/dl) & 0.76 & 0.05 & 1.83 & 0.18 & 0.001 \\
\hline Albumin (g/dl) & 3.38 & 0.13 & 2.62 & 0.42 & 0.001 \\
\hline sCD163 (ng/ml) & 2.89 & 0.02 & 8.71 & 2.42 & 0.13 \\
\hline
\end{tabular}

Table (3): Comparison of the characteristics (categorical variables) of patients with $\mathrm{OV}$

\begin{tabular}{|l|l|c|c|c|}
\hline \multirow{2}{*}{ Sex } & & $\begin{array}{c}\text { Group II } \\
\text { (Small OV) }\end{array}$ & $\begin{array}{c}\text { Group IIb } \\
\text { (Large OV) }\end{array}$ & \multirow{2}{*}{ P value } \\
\hline \multirow{3}{*}{ Child-Pugh score } & Male & $13(68.4 \%)$ & $32(69.6 \%)$ & \multirow{2}{*}{0.93} \\
\cline { 2 - 4 } & Female & $6(31.6 \%)$ & $14(30.4 \%)$ & \multirow{2}{*}{0.006} \\
\cline { 2 - 4 } & A & $9(47.4 \%)$ & $13(28.3 \%)$ & \multirow{2}{*}{0.008} \\
\cline { 2 - 4 } & B & $10(52.6 \%)$ & $17(36.9 \%)$ & \multirow{2}{*}{0.005} \\
\hline \multirow{2}{*}{ Ascites } & No & $0(0 \%)$ & $16(34.8 \%)$ & \\
\cline { 2 - 4 } & Yes & $10(52.6 \%)$ & $9(19.6 \%)$ & $3(80.4 \%)$ \\
\end{tabular}


Table (4): Comparison of the characteristics (numerical variables) of patients with $\mathrm{OV}$

\begin{tabular}{|l|c|c|c|c|c|}
\hline \multirow{2}{*}{} & \multicolumn{2}{|c|}{$\begin{array}{c}\text { Group IIa } \\
\text { (Small OV) }\end{array}$} & \multicolumn{2}{c|}{$\begin{array}{c}\text { Group IIb } \\
\text { (Large OV) }\end{array}$} & \multirow{2}{*}{ P value } \\
\cline { 2 - 5 } & Mean & SD & Mean & SD & \\
\hline Age (years) & 57.68 & 10.01 & 56.89 & 8.36 & 0.74 \\
\hline Hemoglobin (g/dl) & 9.18 & 2.46 & 8.7 & 2.02 & 0.41 \\
\hline Total leucocytic count (x10 $/$ /ul) & 7.12 & 3.99 & 5.77 & 1.92 & 0.13 \\
\hline Platelet count (x10 $\mathbf{3} / \mathbf{u l})$ & 130.26 & 7.59 & 95.04 & 6.71 & 0.028 \\
\hline AST (U/L) & 62.95 & 5.89 & 52.93 & 7.96 & 0.08 \\
\hline ALT (U/L) & 58.53 & 7.7 & 50.33 & 9.02 & 0.17 \\
\hline INR & 1.53 & 0.34 & 1.46 & 0.06 & 0.47 \\
\hline Serum creatinine (mg/dl) & 1.29 & 0.05 & 1.41 & 0.13 & 0.67 \\
\hline Serum Na ( mEq/L ) & 134.84 & 6.13 & 133.48 & 6.68 & 0.45 \\
\hline Total Bilirubin (mg/dl) & 2.08 & 0.83 & 1.72 & 0.07 & 0.26 \\
\hline Albumin (g/dl) & 2.89 & 0.35 & 2.51 & 0.40 & 0.001 \\
\hline sCD163 (ng/ml) & 3.75 & 0.22 & 10.75 & 0.26 & 0.001 \\
\hline
\end{tabular}

Table (5): Major variceal bleeding in patients with small OV in comparison to patients with large OV

\begin{tabular}{|c|c|c|c|}
\hline Major variceal bleeding & $\begin{array}{c}\text { Group IIa } \\
\text { (Small OV) } \\
\text { N= 19 }\end{array}$ & $\begin{array}{c}\text { Group IIb } \\
\text { (Large OV) } \\
\mathbf{N = 4 6}\end{array}$ & P value \\
\hline Yes & $8(42.1 \%)$ & $33(71.7)$ & 0.024 \\
No & $11(57.9)$ & $13(28.3)$ & \\
\hline
\end{tabular}

Table (6): ROC curve analysis of $\mathrm{SCD} 163$ value in diagnosis of $\mathrm{OV}$ and large $\mathrm{OV}$

\begin{tabular}{|l|l|l|l|l|l|l|l|l|l|c|}
\hline & Cutoff & AUC & $\begin{array}{c}\text { 95\% } \\
\text { CI }\end{array}$ & Sensitivity & Specificity & PPV & NPV & $\begin{array}{c}\text { Positive } \\
\text { likelihood } \\
\text { ratio }\end{array}$ & $\begin{array}{c}\text { Negative } \\
\text { likelihood } \\
\text { ratio }\end{array}$ & P value \\
\hline $\begin{array}{l}\text { Any size } \\
\text { OV }\end{array}$ & 3.58 & 0.93 & $\begin{array}{l}0.86- \\
1.0\end{array}$ & $90.8 \%$ & $80.0 \%$ & $98.3 \%$ & $40 \%$ & 9.87 & 0.25 & 0.001 \\
\hline $\begin{array}{l}\text { Large } \\
\text { OV }\end{array}$ & 4.45 & 0.95 & $\begin{array}{l}0.89- \\
1.0\end{array}$ & $89.1 \%$ & $84.2 \%$ & $93.2 \%$ & 76.2 & 8.17 & 0.19 & 0.001 \\
\hline
\end{tabular}

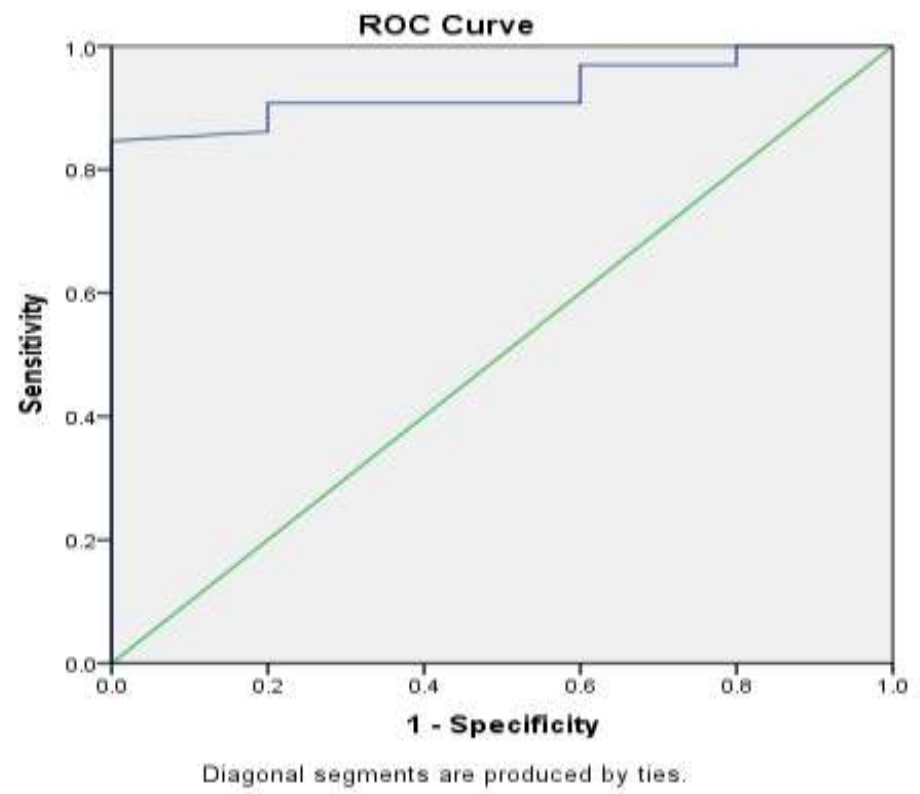

Figure (2): ROC curve of sCD163 value for the presence of OV. 


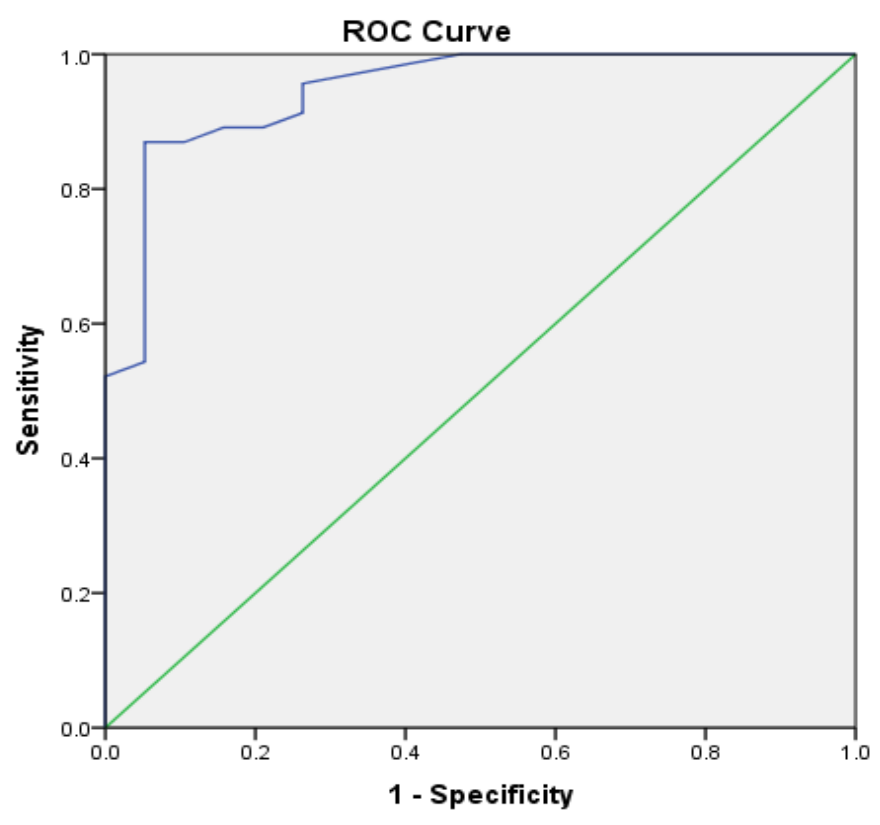

Diagonal segments are produced by ties.

Figure (3): ROC curve analysis of sCD163 value in diagnosis of large esophageal varices.

Table (7): ROC curve analysis of sCD163 value in detecting major variceal bleeding in patients with OV

\begin{tabular}{|c|c|c|c|c|c|c|c|c|c|}
\hline Cutoff & AUC & $\begin{array}{c}\text { 95\% } \\
\text { CI }\end{array}$ & Sensitivity & Specificity & PPV & NPV & $\begin{array}{c}\text { Positive } \\
\text { likelihood } \\
\text { ratio }\end{array}$ & $\begin{array}{c}\text { Negative } \\
\text { likelihood } \\
\text { ratio }\end{array}$ & P value \\
\hline 4.63 & 0.62 & $\begin{array}{c}0.48- \\
0.76\end{array}$ & $70.7 \%$ & $54.2 \%$ & $72.5 \%$ & $52.0 \%$ & 2.41 & 0.85 & 0.001 \\
\hline
\end{tabular}

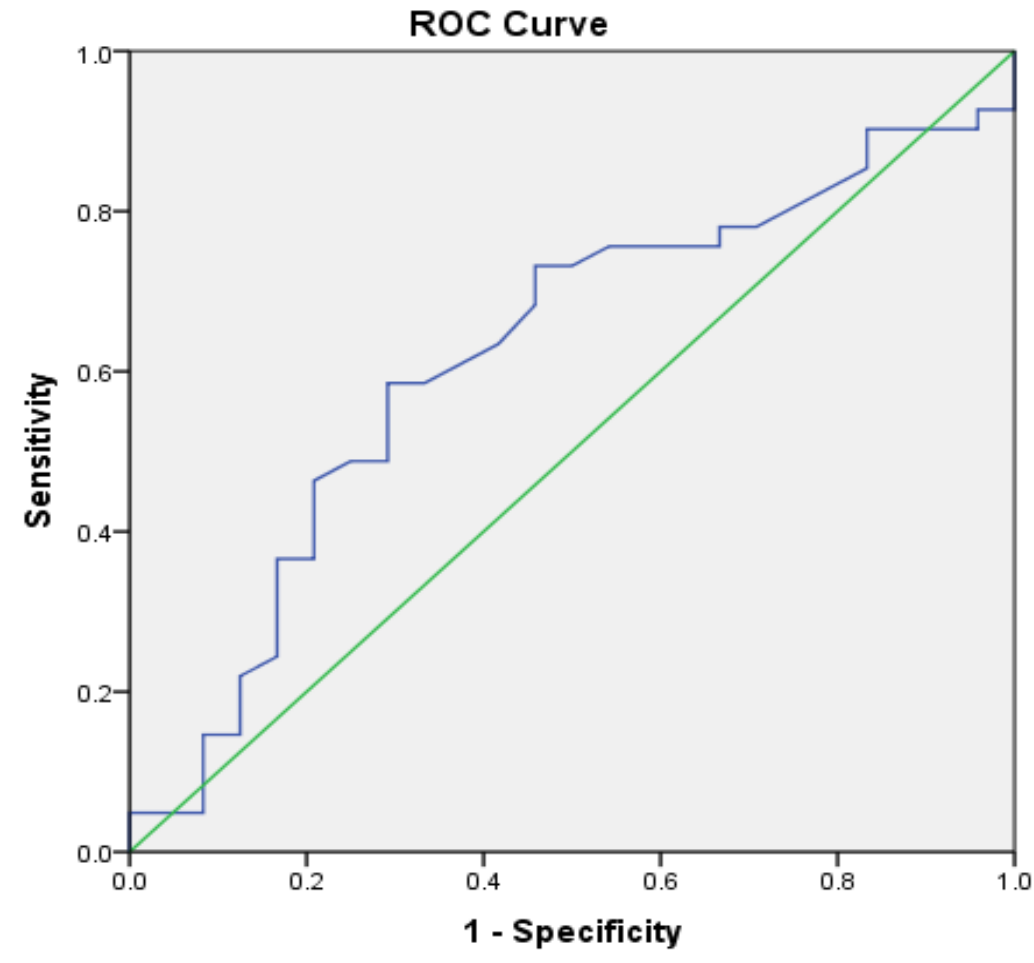

Diagonal segments are produced by ties.

Figure (4): ROC curve analysis of sCD163 value in detecting major variceal bleeding in patients with OV. 
Table (8): Analysis of different parameters in patients with major variceal bleeding in comparison to patients without variceal bleeding

\begin{tabular}{|l|c|c|c|}
\hline Different Parameters & Positive 41 (63.1 \%) & Negative 24 (36.9 \%) & P value \\
\hline Splenomegaly & $35(85.4 \%)$ & $20(83.3 \%)$ & 1.0 \\
\hline Ascites & $31(75.6 \%)$ & $15(62.5 \%)$ & 0.26 \\
\hline sCD163( $\geq 4.63 \mathrm{ng} / \mathrm{ml})$ & $29(70.7 \%)$ & $11(45.8 \%)$ & 0.001 \\
\hline Platelets $(\mathrm{x} 103 / \mathrm{mm} 3)$ & $95.93 \pm 52.44$ & $121.42 \pm 67.08$ & 0.09 \\
\hline Albumin $(\mathrm{g} / \mathrm{dl})$ & $2.57 \pm 0.42$ & $2.7 \pm 0.43$ & 0.22 \\
\hline Bilirubin $(\mathrm{mg} / \mathrm{dl})$ & $1.63 \pm 0.74$ & $2.16 \pm 1.65$ & 0.08 \\
\hline Large OV & $33(80.5 \%)$ & $13(54.2 \%)$ & 0.024 \\
\hline Child Class & & & \\
A & $10(24.4 \%)$ & $12(50 \%)$ & 0.07 \\
B & $21(51.2 \%)$ & $6(25 \%)$ & \\
C & $10(24.4 \%)$ & $6(25 \%)$ & \\
\hline
\end{tabular}

\section{DISCUSSION}

Cirrhotic patients have a 40 percent risk of producing $\mathrm{OV}{ }^{(9)}$. The most common and vital portosystemic shunts that form as a result of portal hypertension are the OV shunts. Variceal bleeding may be reduced by $50 \%$ with endoscopic prophylactic band ligation and non-selective beta-blockers ${ }^{(10)}$. It is advised to conduct an upper GI endoscopy as soon as there are some symptoms of LC in the patients to prevent bleeding from $\mathrm{OV}{ }^{(11)}$. Endoscopic screening of all cirrhotic cases will result in a significant number of needless endoscopies, putting patients and endoscopic units under added strain. As a result, more precise noninvasive $\mathrm{OV}$ prediction parameters can minimize the need for upper GI endoscopies in variceal screening (12). Our research focused on the diagnostic utility of serum sCD 163 as a non-invasive indicator of the existence of $\mathrm{OV}$ in cirrhotic patients, as well as its predictive potential for prediction of the size of $\mathrm{OV}$ and the risk of variceal bleeding. The importance of liver macrophages (Kupffer cells) in the fibrotic phase has been highlighted in studies ${ }^{(13)}$. Macrophage-specific indicators, such as serum sCD163, can therefore be useful for tracking fibrosis progression ${ }^{(14)}$. Active macrophages shed these endocytic macrophage surface receptors during inflammation ${ }^{(15)}$. Rdgaard-Hansen et al. ${ }^{(14)}$ were the first to suggest that macrophagerelated sCD163 could be used as fibrosis biomarkers. This serum marker reflects monocyte/macrophage activation and is easily detectable.

In our research, we concluded that serum bilirubin level is a reliable indicator of the existence of OV (Pvalue of 0.001), which agrees with Kadohara et al. ${ }^{(16)}$, but its level is not correlated with the grade of varices, as there was no statistical significant difference between serum bilirubin level in patients with small and large varices $(\mathrm{P}>0.05)$.

There was an association between serum albumin level and the occurrence of OV (P-value of 0.001), which is consistent with Vanbiervliet et al. (17) findings. There was also a statistical difference in serum albumin levels between patients with small and large varices (P-value of 0.001), which is consistent with Chang ${ }^{(18)}$ and Sarwar et al. ${ }^{(19)}$ findings.

Lower platelet count was associated with the presence of OV in this study, with a mean count of $(102.58 \pm 59.55) \times 10^{3} / \mathrm{mm}^{3}$ in variceal patients versus $(164.6 \pm 79.63) \times 10^{3} / \mathrm{mm}^{3}$ in non-variceal patients $(\mathrm{P}<$ $0.05)$, and the lower count was also significant $(\mathrm{P}<$ $0.05)$ in predicting the higher grade of varices, with a mean count of $(95.04 \pm 60.71) \times 10^{3}$. These findings were in agreement with Sarwar et al. (19) and Thomopolous et al. (20), but not in agreement with Dittrich et al. ${ }^{(21)}$ and Hong et al. ${ }^{(22)}$.

Splenomegaly was a marker of OV, with splenomegaly in 20 percent of non-variceal patients versus 84.6 percent of variceal patients $(\mathrm{P}=0.001)$, and splenomegaly was present in 63.2 percent of patients with small esophageal varices versus 93.5 percent of patients with large $\mathrm{OV}(\mathrm{P}=0.001)$. This is in line with the findings of Vizzutti et al. ${ }^{(23)}$, Sarangapani et al. (24) and Cherian et al. ${ }^{(25)}$.

According to the findings of Schepis et al. ${ }^{(26)}$ and Burton et al. ${ }^{(27)}$, we also found that ascites is a reliable non-invasive parameter for predicting the prevalence of OV, with $20 \%$ of non-variceal patients were ascetic versus 70.8 percent of variceal patients (P 0.037), and that the presence of ascites will predict the higher grade of varices, with 47.4 percent of patients with small OV were ascitic versus 80.4 percent of patients with large ones ( $\mathrm{P}=0.008) . \mathbf{~ N g}$ et al. ${ }^{(28)}$ and Thomopalous et al. (20) all came to similar conclusions.

In our research, we found that patients in ChildPugh class B or C are more likely to have varices on upper GI endoscopy than patients in Child-Pugh class A, which agrees with Zaman et al. ${ }^{(29)}$ but differs from Burton et al. ${ }^{(27)}$, Hong et al. ${ }^{(22)}$, and Qamar et al. ${ }^{(30)}$. We also found that larger varices were associated with more advanced Child-Pugh classes, with more prevalent instances getting larger varices in classes B 
and C, which agrees with Zaman et al. ${ }^{(31)}$ and Zoli et al. ${ }^{(32)}$, but not with Wang et al. ${ }^{(33)}$.

A major Chinese analysis involving nearly 1000 patients with cirrhosis who had no prior history of bleeding found that sCD163 was substantially higher in patients with varices relative to patients without varices, with a sensitivity of $80 \%$ and a specificity of 89 percent ${ }^{(34)}$. Just a few clinical studies have looked at the risk predictive ability of sCD163 for the event of severe varices bleeding. Hepatic venous pressure gradient (HVPG) $>10 \mathrm{mmHg}$ can be predicted by sCD163 serum levels >3.95 ng/ml, which closely correlates with the likelihood of variceal bleeding ${ }^{(34)}$. Waidmann et $\boldsymbol{a l} .{ }^{\left({ }^{35)}\right.}$ observed that patients with a sCD163 serum concentration $>4.1 \mathrm{ng} / \mathrm{ml}$ have a greater rate of significant bleeding cases than patients with lower sCD163 serum concentrations, furthermore, reported that the assessment of sCD163 was superior to the endoscopic grading of varices for prediction of GI bleeding in the multivariate analysis, and higher sCD163 levels were associated with increased risk of bleeding independently of red spots ${ }^{(34)}$.

We noted that mean serum values of sCD163 were higher in cirrhotic patients with $\mathrm{OV}$ with a mean value of $8.71 \pm 8.42 \mathrm{ng} / \mathrm{ml}$ than in cirrhotic patients without $\mathrm{OV}$ with a mean value of $2.89 \pm 1.02 \mathrm{ng} / \mathrm{ml}$ in this analysis, but this was not statistically important ( $\mathrm{P}$ $=0.13$ ), which agrees with Yang et al. ${ }^{\text {(34) }}$ and Waidmann et al. (35). However, serum levels of sCD163 were higher in cirrhotic patients with large OV (mean value $10.75 \pm 9.26 \mathrm{ng} / \mathrm{ml}$ ) than in cirrhotic patients with small OV $(3.75 \pm 0.92 \mathrm{ng} / \mathrm{ml})$, which was statistically significant $(\mathrm{P}=0.001)$ and agrees with Waidmann et al. ${ }^{(35)}$.

In our study, sCD163 had a sensitivity of 90.8 percent, a specificity of 80.0 percent, a PPV of 98.3 percent, NPV of 40.0 percent, and ROC analysis calculated AUC of 0.93 for predicting the presence of $\mathrm{OV}$ with a $\mathrm{P}$ value of 0.001 , and at cutoff value 4.45 $\mathrm{ng} / \mathrm{ml}$, it had 89.1 percent sensitivity, 84.2 percent specificity, a PPV of 93.2 percent, with a P-value of 0.001 , this research found that serum sCD163 level at cutoff value $4.63 \mathrm{ng} / \mathrm{ml}$ had 70.7 percent sensitivity, 54.2 percent specificity, 72.5 percent $\mathrm{PPV}$, and 52.0 percent NPV for predicting the occurrence of severe variceal bleeding in cirrhotic patients with $\mathrm{OV}$ independent of variceal grade. Only large OV, the appearance of red patches, and a serum sCD163 concentrations of more than $4.63 \mathrm{ng} / \mathrm{ml}$ were found to be closely correlated with the occurrence of major variceal bleeding, which is in agreement with Waidmann et al. ${ }^{\text {(35) }}$.

The study's drawbacks include the limited number of participants and the cross-sectional design, which precludes any evaluation of sCD163 as a marker for disease control or care result. However, to the best of our understanding, this is one of the few researches to look at the predictive ability of sCD163 for variceal bleeding in patients with liver cirrhosis in a homogeneous community.

\section{CONCLUSION}

It could be concluded that serum sCD163 could be a non-invasive indicator of the presence of $\mathrm{OV}$ in cirrhotic patients. It may also be used for grading OV and as a new independent predictor of severe variceal bleeding.

Data Availability: On fair request, the corresponding author can include the datasets utilized and evaluated throughout the present analysis.

Funding: Not Available.

Conflicts of interest: Not Available.

\section{REFERENCES}

1. Nusrat S, Khan M, Fazili J et al. (2014): Cirrhosis and its complications: evidence-based treatment. World J Gastroenterol., 20:5442-6.

2. De franchis $\mathbf{R}$ (2010): Revising consensus in portal hypertension: Report of the Baveno $\mathrm{V}$ consensus workshop on definitions, methodology, and therapy in portal hypertension. J Hepatol., 53:762-68.

3. Berzigotti A, Gilabert R, Abraldes J et al. (2008): Non-invasive prediction of clinically significant portal hypertension and oesophageal varices in patients with compensated liver cirrhosis. Am J Gastroenterol., 103(5):1159-67.

4. Steib C (2011): Kupffer cell activation and portal hypertension. Gut, 60: 1307-1308.

5. Moestrup S, Moller H et al. (2004): CD163: a regulated hemoglobin scavenger receptor with a role in the anti-inflammatory response. Ann Med., 36:347354.

6. Etzerodt A, Maniecki M, Moller K et al. (2010): Tumor necrosis factor alpha-converting enzyme (TACE/ADAM17) mediates ectodomain shedding of the scavenger receptor CD163. J Leukocyte Biol., 88:1201-1205.

7. Schaer D, Schleiffenbaum B, Kurrer M et al. (2005): Soluble hemoglobin-haptoglobin scavenger receptor CD163 as a lineage-specific marker in the reactive hemophagocytic syndrome. Eur J Haematol., 74:6-10.

8. Holland-Fischer P, Gronbaek H, Sandahl T et al. (2011): Kupffer cells are activated in cirrhotic portal hypertension and not normalised by TIPS. Gut, 60:1389-1393.

9. Pagliaro L, D'Amico G, Pasta L et al. (1999): Portal hypertension in cirrhosis: natural history. In: Bosch J, Groszmann RJ, editors. Portal Hypertension: Pathophysiology and Treatment. Oxford: Blackwell Science, Pp. 72-92.

10. Giannelli V, Lattanzi B, Thalheimer U et al. (2014): Beta-blockers in liver cirrhosis. Ann Gastroenterol., 27 (1): 20-26. 
11. Denzer U, Beilenhoff U, Eickhoff A et al. (2015): S2k guideline: quality requirements for gastrointestinal endoscopy, AWMF registry no. 021022. Z Gastroenterol., 53:1-227.

12. Wang L, Hu J, Dong S et al. (2014): Non-invasive prediction of large esophageal varices in liver cirrhosis patients. Clin Invest Med., 37 (1): E38-46.

13. Wynn T, Barron L (2010): Macrophages: master regulators of inflammation and fibrosis. Semin Liver Dis., 30:245-257.

14. Rodgaard-Hansen S, Rafique A, Christensen P et al. (2014): A soluble form of the macrophage-related mannose receptor (MR/CD206) is present in human serum and elevated in critical illness. Clin Chem Lab Med., 52:453-461.

15. Hintz K, Rassias A, Wardwell $K$ et al. (2002): Endotoxin induces rapid metalloproteinase-mediated shedding followed by up-regulation of the monocyte hemoglobin scavenger receptor CD163. J Leukocyte Biol., 72:711-717.

16. Kadohara M, Kawasaki H, Hirayama C (1987): Serum bile acids and oral ursodeoxycholic acid tolerance test in the diagnosis of oesophageal varices. Gastroenterology J., 22(5): 615-620.

17. Vanbiervliet G, Barjoan-Marine E, Anty $\mathrm{R}$ et al. (2005): Serum fibrosis markers can detect large esophageal varices with a high accuracy. European J. of Gastroenterology. Hepatol., 17 (3): 333-338.

18. Chang M, Sohn J, Kim T et al. (2007): Nonendoscopic predictors of large esophageal varices in patients with liver cirrhosis. Korean J. Gastroenterology, 49 (6): 376-383.

19. Sarwar S, Khan A, Alam A et al. (2005): Nonendoscopic prediction of presence of esophageal varices in cirrhosis. J Coll Physicians Surg Pak., 15:528-531.

20. Thomopoulos K, Labropoulou-Karatza C, Mimidis K et al. (2003): Non-invasive predictors of the presence of large oesophageal varices in patients with cirrhosis. Dig Liver Dis., 35:473-478.

21. Dittrich S, de Mattos A, Cheinquer H et al. (2005): Correlation between platelet blood levels and the hepatic venous pressure gradient among patients with cirrhosis. AR Gastroenterology, 42 (1): 35-40.

22. Hong $W$, Zhu $Q$, Huang $Z$ et al. (2009): Predictors of esophageal varices in patients with HBV-related cirrhosis: a retrospective study. BMC Gastroenterol., 9:11-15.

23. Vizzutti F, Arena U, Romanelli R et al. (2007): Liver stiffness measurement predicts severe portal hypertension in patients with HCV-related cirrhosis. Hepatology, 45:1290-1297.

24. Sarangapani A, Shanmugam $C$, Kalyanasundaram M et al. (2010): Non-invasive prediction of large esophageal varices in chronic liver disease patients. Saudi J Gastroenterol., 16:38-42.

25. Cherian J, Deepak N, Ponnusamy R et al. (2011): Non-invasive predictors of esophageal varices. Saudi J Gastroenterol., 17:64-68.

26. Schepis F, Camma C, Niceforo D et al. (2001): Which patients with cirrhosis should undergo endoscopic screening for esophageal varices detection? Hepatology, 33:333-338.

27. Burton J, Liangpunsakul S, Lapidus J et al. (2007): Validation of a multivariate model predicting presence and size of varices. Journal of Clinical Gastroenterology, 41(6): 609-615.

28. Ng F, Wong S, Loo C et al. (1999): Prediction of esophagogastric varices in patients with liver cirrhosis. Gastroenterology and Hepatology J., 14 (8): 785-790

29. Zaman A, Beker T, Lapido J et al. (2001): Risk factors for the presence of varices in cirrhotic patients without a history of variceal hemorrhage. Arch Intern Med., 161: 2564- 2570.

30. Qamar A, Grace N, Groszmann R et al. (2008): Platelet count is not a predictor of the presence or development of gastroesophageal varices in cirrhosis. Hepatology, 47(1): 153-159.

31. Zaman A, Hapke R, Flora K et al. (1999): Factors predicting the presence of esophageal or gastric varices in patients with advanced liver disease. American Journal of Gastroenterology, 94(11): 3292 3296.

32. Zoli M, Merkel C, Magalotti D et al. (2000): Natural history of cirrhotic patients with small esophageal varices a prospective study. Am J Gastroenterology, 95 (2): 503-508.

33. Wang L, Hu J, Dong S et al. (2014): Non-invasive prediction of large esophageal varices. Clin Inest Med., 37(1): 38-46.

34. Yang Y, Hou M, Lin M et al. (2013): Combined platelet count with sCD163 and genetic variants optimizes esophageal varices prediction in cirrhotic patients. J Gastroenterol Hepatol., 28(1):112-121.

35. Waidmann O, Brunner F, Herrmann E et al. (2013): Macrophage activation is a prognostic parameter for variceal bleeding and overall survival in patients with liver cirrhosis. J Hepatol., 58(5):956961. 